\title{
- 'MANY RIVERS TO CROSS': Suburban Densification and the Social Status Quo in Greater Lyon
}

\author{
MAX ROUSSEAU
}

\begin{abstract}
Urban research often considers densification from the perspective of sustainable development and social mix. This essay focuses instead on the social and political stakes involved in densification through the example of a large French metropolitan area. It shows that the densification policies put in place in the Lyon agglomeration cannot be said to succeed in breaking down the historical segregation between its residential and affluent western suburbs (banlieues) and its industrial and working-class eastern ones. The political manoeuvres executed by the institutions implementing densification, and the search for consensus characterizing France's intercommunalities, block any possibility of redistributing functions and social classes at the metropolitan scale, and hence of ending the social specialization of Lyon's suburbs. Moreover, municipalities subjected to pressure from suburban areas carefully assess the profile of residents selected to occupy new housing units-i.e. individuals already residing in the commune in the case of western suburbs, and middle-class individuals hailing from the eastern part of the agglomeration in the case of eastern suburbs. Densification does not foster social mix at the metropolitan scale, neither does it improve the housing conditions of disadvantaged populations.
\end{abstract}

\section{Introduction: densifying the suburbs (banlieues) of large French cities}

France has undergone two successive waves of suburbanization since the second world war. From the 1940s to the early 1970s, French Fordism and the urbanization model that sustained it were closely regulated by the state, in contrast to the North American model where the private sector had much greater scope to take advantage of public investment beyond the limits of the inner cities (Filion, 2014, this issue). This explains the post-war French preference for a denser form of suburbanization, manifested mainly through the construction of public collective housing. Conceived as a planning tool for the harmonious distribution of workers and economic activities throughout France, the planning policy of large housing estates effectively subscribed to the 'spatial Keynesianism' of the Fordist era (Brenner, 2004). During the 1970s, however, after noting a degree of alleviation in the housing crisis (plus fresh aspirations for homeownership and greater demand for individual houses), the government changed its urbanization strategy, as evidenced in France's second wave of suburbanization (Steinmetz, 2013). From this moment on, France's metropolitan areas seem to have undergone the same long-term population trends as seen in the United States over the last four decades: a general decline of the inner cities, with growth rates in the suburban ring continuously on the increase (Bae and Richardson, 2005: 4).

- $\quad$ The impetus to densify in a fragmented suburban territory

This second wave of suburbanization contrasted with the first wave in every respect: the private sector supplanted state interventionism, individual homeownership replaced rental, private housing was favoured over public housing, and individual

\footnotetext{
This essay is based on the findings of research financed by the 'Sustainable Cities' programme of the French Agency for Research. I would like to thank Eric Charmes, Roger Keil, those who attended the 'Suburbs and Densification: Local Resistance and Dynamics of Change' session at the Conference of the Association of American Geographers in New York (where a previous version of this essay was discussed) and finally the three anonymous IJURR reviewers for their comments, which helped me greatly in improving this text.
} 
houses became sought after in preference to properties on collective housing estates. This second wave of suburbanization is characterized by geographical dispersion, resulting in a transfer of metropolitan growth towards more remote peripheries and a general lowering of urban densities (Pumain, 2005). Lastly, this second wave of suburbanization has enabled the white middle class to separate itself spatially from a multi-ethnic working class, now 'trapped' on the large housing estates built during the first wave (Cartier et al., 2008; Tissot, 2008). Indeed, the industrial crisis and the emergence of a post-Fordist dual labour market quickly led to the social specialization of the different housing types developed during the two waves of suburbanization. Thus the connection between large housing estates and single-family houses-as evidenced by the classic residential trajectory of the middle class from home rental on a large housing estate to single-family house purchase-was rapidly undone. In the early 1980s, the first riots to erupt in Lyon's eastern suburbs and the ensuing 'moral panic' (Wacquant, 2006) added a symbolic dimension to the economic and social features of large housing estates. The post-Fordist suburban landscape which emerged across the biggest French metropolises was broadly characterized by strong social heterogeneity, and ferocious political competition between cities and the suburban communes, ${ }^{1}$ or among the suburban communes themselves (Hoffman-Martinot, 2005).

It is in this context of continuous fragmentation of the suburban landscape that the central state's urbanization framework has recently been modified. From the 1990s onwards, the second wave of suburbanization has increasingly been called into question, as the principles of sustainable urban development have attained prominence in Western countries and the 'compact city' model has diffused internationally (Andres and Sadoux, 2005). In concrete terms, the modification of the French state's urban framework is reflected in a series of legislative changes aimed at favouring brownfield redevelopment-notably the 2000 Law on Solidarity and Urban Renewal (SRU), which promotes densification of the urban fabric.

This promotion of the 'compact city' model is based on presuppositions as to environmental and economic benefits (see Charmes and Keil, 2014, this issue). The social dimension of policies of suburban densification, however, has not been seriously examined in urban research. And yet, in addition to favouring urban renewal, one of the main objectives of the SRU legislation has been to generate social mix (Epstein and Kirszbaum, 2003). In other words, the new legislation on urban renewal seeks to promote not only morphological change (densification), but sociological change (social mix) as well-though these two dimensions are not explicitly connected in the SRU legislation. However, the new legislation appears to be politically embedded, part of a general shift in the institutional organization of the big metropolises, with the central state strengthening the development of intercommunal organizations ${ }^{2}$ for decisionmaking and planning through the adoption of the 1999 Chevènement Law. This means that as soon as densification became one of the main objectives of the central state with regard to suburbanization, it also became an intercommunal issue. However, despite theoretically stronger intercommunal integration through the creation of new intercommunal planning documents, the suburban communes still manage to protect their interests thanks to an intercommunal process of decision-making built on the creation of consensus (Desage and Guéranguer, 2011). Moreover, the effective application of the SRU legislation still relies partly on the action of municipalities that retain some of their previous powers over urban planning, and hence can potentially orient densification's social dimension in a direction that deviates from the official spirit of the national legislation. 
How is the impetus to densify perceived in the highly heterogeneous (historically, economically and socially) urban landscape formed by suburbs? Given that the densification and morphological transformation of cities entails the potential alteration of urban populations' social composition, is densification likely to reverse the fragmentation and segregation processes now reshaping France's suburbs? Can densification add a social dimension to the environmental dimension of sustainable urban development by favouring social mix at the metropolitan scale?

\section{- $\quad$ Objectives, method and presentation of the case study}

The question of how municipalities construe densification appears crucial to comprehending the negotiations shaping the implementation of metropolitan policies of densification. This essay aims to demonstrate that densification in suburbs involves significant political stakes, though these differ vastly depending on the economic and social profile of individual communes. In low-rise residential communes forged in the second wave of suburbanization, the pressure to densify from upper levels of government is perceived as likely to thwart efforts to preserve a socially homogeneous community, and is hence viewed with suspicion. Densification in this context is the object of tough negotiations between municipalities and intercommunal structures. On the other hand, in working-class communes that developed during the first wave of suburbanization and have declined in the post-Fordism years, the impetus to densify is seen primarily as an opportunity. In effect, municipalities in these communes do not pursue a strategy of status quo preservation, but an urban development approach. In the end, however, municipalities and established residents in both types of territory carefully assess the social profile of newcomers, thereby limiting the supposed effects of densification (conceived as the advent of social mix at the metropolitan scale).

The site selected for the comparative study of local densification policies is the Lyon agglomeration (France's second largest), whose centre comprises the city of Lyon and the commune of Villeurbanne. Marked by historical segregation between its western (residential, affluent, composed of single-family homes) and eastern (industrial, working-class, surrounded by large housing estates) suburbs, this site is of obvious interest to researchers (see Figure 1 for a map on income segregation in the Lyon agglomeration). Indeed, it is constituted by a group of highly disparate territories that display heterogeneous morphological, economic, social and political features, yet all of which have come under increasing pressure to densify from the central state and the metropolitan government (the Urban Community of Lyon, also known as Greater Lyon) over the last decade. This essay is based on approximately 20 semi-structured interviews conducted with elected representatives and administrative managers of communes located within Lyon's inner suburbs (the area that truly corresponds to the definition of a 'suburban territory', i.e. urban territories linked to the central city via a continuous urban fabric). While the research spanned the diversity of Lyon's suburbs, I have focused here for heuristic reasons on the richest communes of the western suburbs and on the poorest communes of the eastern suburbs: these contrasted cases help to measure the diversity of the negotiations between the suburban communes and the intercommunal organization about the densification imperative. Lastly, the study was complemented by interviews conducted with elected representatives and administrative managers of Greater Lyon's intercommunal structure.

\section{The metropolitan compromise: densifying the Lyon suburbs while preserving the historical status quo}

It is important to mention at the outset that the densification policy promoted by the central state echoes Greater Lyon's growing concerns with the economic competitiveness of the city at the global scale. Under the influence of a new generation of elected representatives in the early 1990s, Greater Lyon embarked on a definitive path 


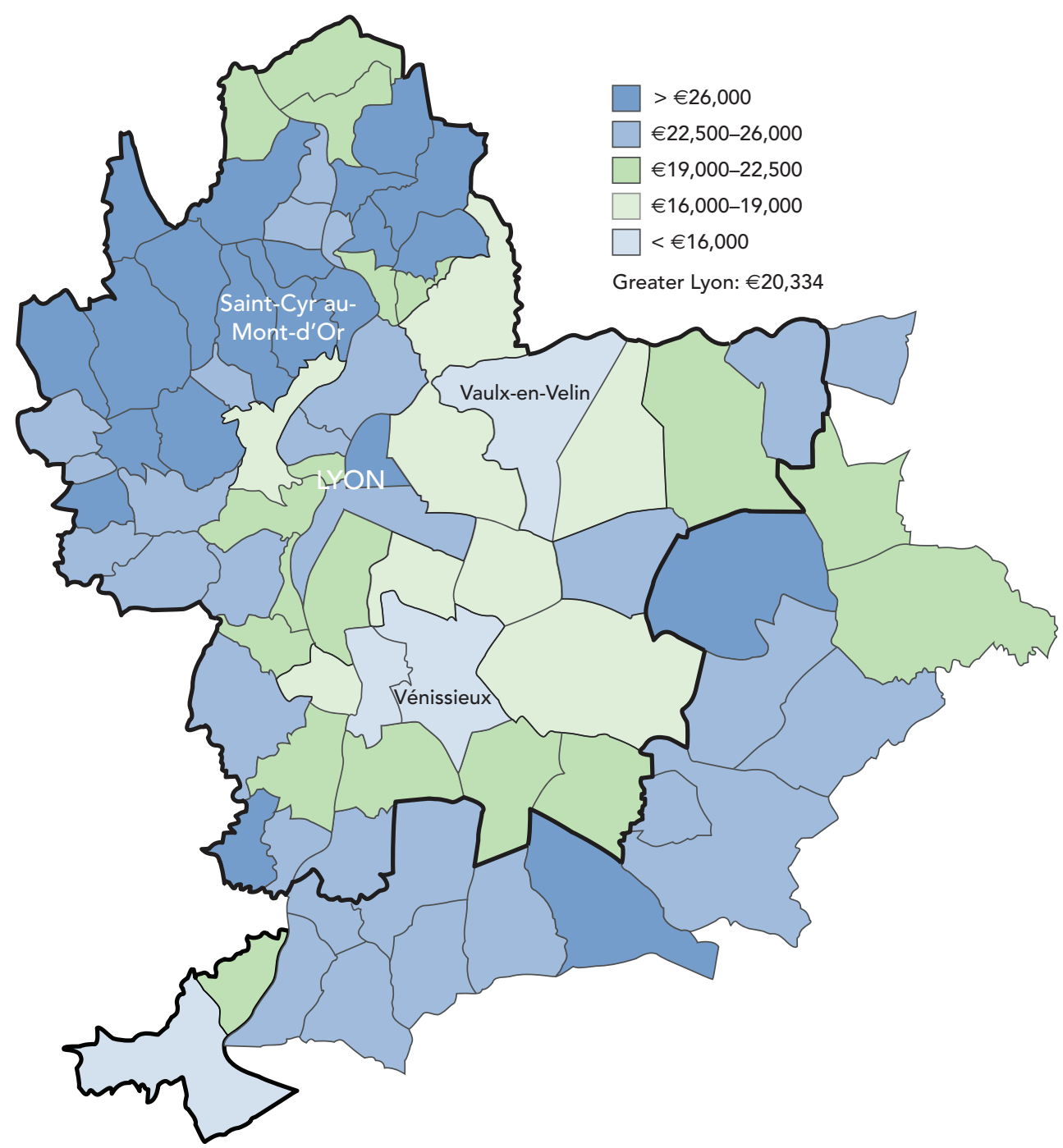

FIGURE 1 Median annual household income in the Lyon agglomeration, 2011 (source: Agence d'Urbanisme de Lyon, Insee-RFL)

of entrepreneurial economic development, pursuing a strategy centred on attracting external investments and expanding its service sector (Jouve, 2001). This new discourse, however, rapidly encountered competition from urban peripheries located outside Greater Lyon's zone of influence. In effect, Greater Lyon comprises 59 communes and 1.3 million inhabitants, while the Lyon urban area ${ }^{3}$ includes 514 communes and 2.1 million inhabitants. In this context, the Urban Community of Lyon has de facto been forced to compete with its periphery, which is composed of small periurban communities undergoing significant expansion as a result of urban sprawl (Charmes, 2011). Given the relative scarcity of available land on the territory governed by Greater Lyon (coupled with the consensus on preservation of existing non-built areas), suburban

3 According to the official statistical definition, an urban area is a set of continuous municipalities, without pockets of clear land, comprising an urban centre (an urban unit offering more than 10,000 jobs) and its periphery (communes in which at least $40 \%$ of the resident economically active population works in the urban centre or in the municipalities around it). 
densification has proven increasingly crucial for the economic growth of the Lyon agglomeration over the last decade.

For all that, the implementation of a densification strategy at the metropolitan scale has not entailed the actual redistribution of social classes and economic activities between western and eastern suburbs. Suburban mayors' divergent interests, together with their shared capacity to influence intercommunal policies through Greater Lyon's political structure, have facilitated the search for a compromise on densification. As a result, the political negotiation of densification between municipalities and the intercommunal structure has ensured that suburban densification fails to generate social mix at the scale of a large French metropolitan area.

\section{Western suburbs: limited densification to preserve the social status quo}

Densification constitutes a greater political risk for the mayors of western communes than it does for those of eastern ones, for reasons related primarily to the overall social composition of the two zones. Urban research has clearly highlighted the links between ownership of cultural capital and the frequent occurrence of nimbyism (Sénécal et al., 2002). In the western part of Lyon, residents can more successfully stop densification projects (even very limited ones) by invoking large housing estates and their inhabitants as a counter-model. Thus, in Saint-Didier-au-Mont-d'Or, an affluent western residential commune that grew significantly during the second wave of suburbanization, ${ }^{4}$ a recent project to develop low-rise (i.e. four-floor) mixed housing on a one-hectare lot was immediately denounced, with flyers announcing 'des barres à SaintDidier' ('council housing in Saint-Didier'). ${ }^{5}$ Indeed, most of Lyon's western suburbsand this holds especially true for Saint-Didier-retain a rural aspect inherited from the 'rurbanization' of the 1970s and 1980s (Bauer and Roux, 1976), with an ancient villagelike centre surrounded by a more contemporary low-density form of urbanization (consisting largely of individual houses) linking the western suburban communes to each other. The picturesque aspect of these towns, enhanced by the region's undulating landscape, makes them highly attractive to the bourgeoisie and upper-middle class. In this context, a compromise is frequently forged between the elected representatives of western communes and Greater Lyon: densification via the construction of smallscale collective housing in town centres, in exchange for the preservation of the status quo in residential neighbourhoods situated on large parcels of land. As the elected representative of an affluent western commune suggested:

All majorities have always been terrified of population growth. Population must not be allowed to increase. And yet the general political discourse of Collomb 6 is: "we must welcome a large number of people into the agglomeration each year. Everyone must share the burden". The compromise we worked out was: "the commune must develop. Fine. So we will develop town centres. We will facilitate this" (interview, October 2011). ${ }^{7}$

The compromise on a threefold policy of densification (small-scale collective housing, construction in town centres and strict limits on the proportion of social housing) results from a political strategy pursued by the mayors of Lyon's western communes-a territory traditionally governed by the centre-right. In 2007, a local deputy vying for the presidency of the departmental federation of UMP (Union pour un Mouvement Populaire) Rhône tried to impose the UMP ticket on the mayors of

4 The commune saw its population increase from 3,800 inhabitants in 1968 to 6,200 in 1999.

5 Barres are the rectangular-shaped high-rise concrete housing estates that have become associated with the social problems plaguing areas developed during the first wave of suburbanization.

6 Gérard Collomb is the socialist mayor of Lyon and the president of Greater Lyon.

7 All quotations from the interviews have been translated from French by the author. 
western communes. The latter refused, forming a new centre-right political group named Synergie. The selective opening up of western communes to social housing and densification-firmly opposed by the UMP - created potential common ground for cooperation between the elected representatives of western communes and socialistrun Greater Lyon, consolidating in turn Synergie's presence in the western part of Lyon to the detriment of the UMP. According to the elected representative of a western commune:

In political terms, Collomb needs to negotiate with the western communes. So he made a deal with Synergie on social housing: "Fine. We won't build any barres. We won't develop social housing any old way, but build a few all the same and I will support you". Greater Lyon recognizes that western communes are making efforts in the area of social housing, especially small-scale collective housing. This is the only way to get around administrative appeals (interview, October 2011).

By limiting densification to small-scale collective housing in town centres, municipalities can give a pledge of goodwill to Greater Lyon, whose leaders can then show that the 'burden' of densification weighs equally on western and eastern communes. Elected representatives of the socialist majority in Greater Lyon thus accept the preservation of the status quo in the western part of Lyon. Social mix and the distribution of disadvantaged populations throughout the agglomeration only occur in symbolic measures, ones that Greater Lyon must extract through adept manoeuvring. In the words of Greater Lyon's vice-president of housing:

On the west side of Lyon, social homogeneity prevails, and it has to be preserved. Opening an emergency shelter in the area is politically impossible. We set it up cunningly, behind everyone's back. We do it against people's will (interview, February 2011).

Moreover, if the overall strategy of the metropolis towards densification is henceforth decided at the scale of Greater Lyon, its implementation at the communal scale is subject to strict controls by municipal planning services, which can still employ various tools (e.g. building height restrictions, minimum area of undeveloped space per plot, set distances between existing buildings and/or between buildings and the street, number of additional parking spaces per housing unit, etc.) to limit construction projects deemed too intrusive. Lastly, the densification 'model' prevailing in Lyon's western communes-i.e. densification of town centres within designated development areas $^{8}$-allows mayors to control building together with the social (and ethnic) profile of resident populations, thereby lessening discontent among the electorate. In sum, in residential areas located in the western part of Lyon, the construction of small buildings in town centres has been the result of a compromise acceptable to all parties, in the context of the ascendance of the 'compact city' model-a model now affecting communes originally urbanized in specific accordance with the low-density principle.

The close control of densification in the western suburbs explains why the transformation of urban forms generates only minimal social change. The residents of new buildings do not usually come from communes elsewhere in the Lyon agglomeration, but from the same commune, as densification responds primarily to the needs of an aging population wishing to move closer to shopping facilities in town centres. The important role of mayors in the allocation of social housing, coupled with the now 
mandatory proportion of social housing in new developments (as a result of the SRU legislation introduced in 2000), has made it possible for communes to house young people who would otherwise be forced to move out because of the increase in house prices over recent years. This compromise was clearly explained by the head of the urban planning department of an affluent residential commune located in the western part of Lyon:

During the last elections, the municipal team was reproached for densification. Administrative appeals are lodged when collective housing is built in particular ... The main reproach against densification is that the village character is lost ... Yet the population is aging, particularly in the town centre. Aging people are buying homes so they can live closer to the centre. The housing built in the town centre is mostly for retired people (interview, March 2011).

Thus, the impetus to densify is perceived as a threat in the communes of Lyon's western suburbs. There is a fear of communes losing their 'village cachet' and becoming real 'cities', i.e. foregoing as a result of intensifying urbanization their status as purely residential, socially homogeneous and relatively closed spaces, to become open spaces with diversified functions. Nevertheless, the compromise struck with Greater Lyon as part of a political strategy pursued by the mayors of western communes enables all parties to show that they have accomplished some form of densification, while also maintaining the urban and social status quo.

\section{Eastern suburbs: densification, growth and new-build gentrification}

Densification has received much greater support from the municipalities of Lyon's eastern suburbs, particularly among those communes developed during the first wave of suburbanization that have experienced significant social problems over the last three decades. In contrast to the western suburbs, Lyon's eastern suburbs have a long tradition of industrial activity and are home to an ethnically diversified workingclass population. The main grands ensembles of the metropolis, such as Les Minguettes (Vénissieux) and Le Mas-du-Taureau (Vaulx-en-Velin), and its core transportation infrastructure are located on these eastern plains. In political terms, the communes of the eastern suburbs are more frequently governed by the left. Mayors of these communes belong to the political majority now running Greater Lyon, which gives them input to decisions on community resources-such as public transportation policythat can stimulate densification. In contrast to the situation in the western communes, densification is actively sought in the eastern communes, for two reasons. On the one hand, densification leads to increased demand for community facilities (schools, day nurseries, etc.). Several eastern communes have experienced population decline. As they already have the public facilities needed to meet the demands of a growing population, these communes see densification as a solution to make their facilities viable again. On the other hand, communes in the eastern suburbs view densification primarily as a means of population renewal, by integrating members of the middle class and increasing the turnover among local residents.

Urban research has already shed light on the pursuit of gentrification as a 'solution' to urban decline (Rousseau, 2009). However, in cities where the buildings lack the cachet of 'authenticity' promoting spontaneous gentrification, the recent middle-class influx is better explained by the concept of 'new-build gentrification' (Davidson and Lees, 2005). This extends the notion of gentrification to new residential constructions that have entailed the displacement of a limited number of people. Authors using the term 'new-build gentrification' have also highlighted the improvement of neighbourhoods ensuing from these operations of destruction/reconstruction. Derived from studies of residential transformations in British and North American inner cities 
following industrial decline, this concept applies especially to the towns located in the eastern part of Lyon. Here, the construction of buildings along new public transit corridors in the 2000 s altered social composition without entailing large population transfers. Moreover, public actors have played a crucial role in triggering this type of gentrification (as has also been the case in the Anglophone world).

According to the elected representatives and bureaucrats of Lyon's eastern suburbs, new-build gentrification facilitated by densification helps 'break the pattern of ghettoization', to use the words of an employee of Vénissieux's urban planning department (interview, March 2011). First, middle-class settlement is presumed to reinforce social control in towns where a significant portion of the population is poor. Research has shown that such a representation of gentrification also exists in the Netherlands (Uitermark et al., 2007). Second, middle-class settlement is said to help sustain the development of a resurgent commercial structure in town centres. This has been the case in Vénissieux and Vaulx-en-Velin, two towns of Lyon's inner suburbs with large housing estates dating from the first (post-second world war) wave of suburbanization. Home to an increasingly pauperized working-class population, these communes are notorious nationwide for the riots that have sporadically erupted here since the late 1970s. Taking advantage of the rapid increase in real estate prices in the metropolitan centre, Vénissieux and Vaulx-en-Velin have recently specialized in welcoming one demographic group in particular: 'young, childless, first-time homebuyers hailing principally from the eastern part of Lyon', as identified by Vaulx-en-Velin's director of urban planning (interview, February 2011). In effect, gentrification does not target the wealthy residents of the western communes, but young upwardly mobile households hailing from the east. Thus, the two objectives of the SRU legislation-promoting densification and facilitating the emergence of social mix-conflict with each other: the policy of densification implemented at the local scale does not aim to attract working-class populations into middle-class neighbourhoods, but quite the opposite, calling into question the future localization of the impoverished populations of the eastern suburbs, and ultimately the future of social mix at the metropolitan scale. According to Vaulx-enVelin's director of urban planning, gentrification is construed as follows:

\begin{abstract}
We start from the assumption that the concentration of precarity generates violence and delinquency, but also a contrario that the concentration of wealth contributes to the concentration of precarity in other areas, other territories. What we want to do at the scale of the agglomeration is to break this pattern. This means that, under the watchword of social mix, the contribution of middleclass populations must be sought, as they create new needs and confer a certain modernity on the territory, a certain attractiveness on the territory (interview, February 2011).
\end{abstract}

Urban renewal in Vaulx-en-Velin and Vénissieux therefore represents a significant departure from what occurred on those large housing estates constructed under Fordist urbanization that have long dominated the urban landscape of Lyon's eastern areas, which convey such a negative image associated with communalism (i.e. inward-looking tendencies among immigrant communities), poverty and insecurity. This time, by contrast, urbanization is led by large private real estate groups seeking to reproduce a dense urban form whose classic aesthetics should attract the middle class. Vénissieux provides a good example of this. Formerly a disintegrating industrial landscape located in Lyon's inner suburbs, this working-class town displays an urban fabric that mixes single-family and collective housing with numerous plots earmarked for business purposes. Vénissieux developed during the first wave of suburbanization (its population grew from 15,000 in 1946 to 75,000 in 1975), and for many years a large portion of its inhabitants worked in factories within the commune. Then, overwhelmed 
by social problems following the closure of several factories in the 1970s, the town saw its population decline rapidly (down to 55,000 inhabitants in 1999). Vénissieux experienced a French type of white flight, as the inhabitants who left the commune were primarily those who had access to homeownership. The tower blocks of Les Minguettes-an archetype of 'made in France' suburban Fordism that at the turn of the 1980 s became the scene of riots and the symbol of 'the problem of the banlieues'-were demolished to make way for small-scale collective housing favoured by the municipality. The re-densification observed in Vénissieux since the mid-2000s-whereby the town has regained 7,000 inhabitants-has been promoted by a communist municipality that has taken full advantage of a new public transportation policy developed in conjunction with Greater Lyon.

The reintroduction of the tram in the town centre (together with growing land pressure) has caused the adjacent residential fabric to recently undergo transformation. National developers have been buying houses, re-parcelling the land and building smallscale collective housing targeted at young economically active couples, who work in Lyon yet cannot live in the metropolitan centre due to the rise in real estate prices. The municipality welcomes this type of new-build gentrification not just because it helps generate decent jobs in the town, but also because it prompts the development of a communal commercial structure and hence the creation of a proper town centre in Vénissieux. Moreover, Vénissieux's new attractiveness-as evidenced by a tripling in the number of building permit requests between 2005 and 2010-has strengthened the municipality's hand in negotiating with developers. The municipality can demand more 'quality' and impose architectural constraints on new projects so as to stabilize Vénissieux's new residential status, which is oriented towards young middle-class workers hailing from Lyon's eastern suburbs.

The densification of Lyon's eastern suburbs is facilitated by the relative weakness of nimby mobilizations in the area compared to the western suburbs. Yet movements against densification also exist in the eastern part of Lyon. It is interesting to note that these emanate mainly from the low-rise residential areas that developed or subsisted between large housing estates (Rousseau, 2012). Thus, in Vaulx-en-Velin, contestation is primarily a response to limited densification in the old village centre, which is largely composed of individual houses. Plans for the construction of small-scale collective housing in the neighbourhood have generated increasing opposition on the part of inhabitants-i.e. older lower-middle-class residents, the majority of whom are longterm owner-occupiers. This mobilization has resulted in the creation of an association that is connected to a local political party. Strongly opposed to the construction of any collective apartment building through their fear of large housing estates, the residents of the 'village' have recently succeeded in halting the transformation of their neighbourhood thanks to endless administrative appeals. Despite the fact that the municipalities of eastern industrial communes and real estate groups both want to construct new buildings whose form differs markedly from that of large housing estates, negative associations attaching to those constructions built during the first wave of suburbanization remain sufficiently strong among inhabitants of eastern residential areas to prompt them to mobilize against the new projects. Thus, transcending any rift that divides eastern and western suburbs, primary opposition to densification emanates from a clearly identified urban fabric: residential neighbourhoods, notably those developed during the second wave of densification that are now occupied by the middle class.

\section{Conclusion: landscape transformations and the social status quo}

While densification of the Lyon suburbs has been well underway for the last ten years, the objective of the new national legislation was to supplement landscape transformation with social mutation-on the assumption that densification-induced 
social mix would halt segregatory tendencies observed in large French agglomerations since the failure of the first (post-second world war) wave of suburbanization. Yet the development of intercommunal urban planning policies and the evolution of urban form in the Lyon metropolitan area have not been accompanied by social mix at the metropolitan scale. Inhabitants of the suburbs only rarely cross the two rivers encircling the metropolitan centre to settle in buildings recently erected in communes 'on the opposite side of town'. Moreover, the densification policies put in place in the Lyon agglomeration cannot be said to succeed in softening the historical segregation between the residential and affluent western suburbs and the industrial and working-class eastern ones. On the contrary, the political compromise forged between the mayors of western communes and Greater Lyon has ensured that densification serves to reinforce the residential specialization of the western suburbs. Similarly, the compromise struck between the mayors of eastern communes and Greater Lyon has ensured that densification serves to reinforce the specialization of the eastern suburbs as spaces oriented towards economic development. The political manoeuvres executed by the institutions that implement densification and the search for consensus that characterizes the general functioning of French intercommunalities (Desage and Guéranguer, 2011) limit any possibility of redistributing functions and social classes at the metropolitan scale, and hence of putting an end to the social specialization of the Lyon suburbs.

Additionally, municipalities subjected to pressure from suburban areas assess the profile of residents selected to occupy the new housing units-i.e. individuals who already reside in the commune in the western suburbs, and middle-class individuals hailing from the eastern part of the agglomeration in the eastern suburbs (Cordier, 2011). Thus, densification has limited impact on social mix at the metropolitan scale, and it does not significantly improve the housing conditions of disadvantaged populations. Strictly politically controlled densification specifically seeks to avoid the development of urban forms that would replicate those large housing estates of the first wave of suburbanization-a counter-model that is opportunistically mobilized during municipal elections in Lyon's suburbs. Clearly, the Lyon case demonstrates that the advent of the 'compact city' has not been accompanied by that of the 'mixed city'. Nor has it been accompanied by the advent of the 'just city', defined by Fainstein (2010) as one in which 'primary goods' (especially housing) are accessible on an equitable basis.

Max Rousseau, CIRAD, UMR ART-DEV, 73 rue Jean-François Breton, 34398, Montpellier, Cedex 5, France, max.rousseau@cirad.fr

\section{References}

Andres, L. and S. Sadoux (2005) Reconstruire la ville sur la ville: densités et centralités en France et en Grande Bretagne [Rebuilding the city on the city: densities and centralities in France and Britain]. Paper presented at the conference on 'Développement Urbain Durable, Gestion des Ressources et Gouvernance', Université de Lausanne, Lausanne, 21-23 September.

Bae C.-H.C. and H.W. Richardson (2005) Introduction. In C.-H.C. Bae and H.W. Richardson (eds.), Urban sprawl in Western Europe and the United States, Ashgate, Aldershot.

Bauer, G. and J.-M. Roux (1976) La rurbanisation ou la ville éparpillée ['Rurbanization' or the scattered city]. Éditions du Seuil, Paris.

Brenner, N. (2004) New state spaces. Urban governance and the rescaling of statehood. Oxford University Press, Oxford.

Cartier, M., I. Coutant, O. Masclet and Y. Siblot (2008) La France des 'petits-moyens': enquêtes sur la banlieue pavillonnaire [The France of the 'lower-middle': investigations in suburbia]. La Découverte, Paris.

Charmes, E. (2011) La ville émiettée. Essai sur la clubbisation de la vie urbaine [The scattered city.
Essay on the clubbisation of urban life]. Presses Universitaires de France, Paris.

Charmes, E. and R. Keil (2015) The politics of postsuburban densification in Canada and France. International Journal of Urban and Regional Research 39.3, 581-602

Cordier M. (2011) De la politique du logement aux politiques locales de l'habitat: I'apprentissage de l'action collective négociée [From the politics of accommodation to the local policies of housing: learning negotiated collective action]. Unpublished PhD dissertation, Ecole doctorale Ville, Transports et Territoires, Institut d'Urbanisme de Paris, Créteil.

Davidson, M. and L. Lees (2005) New-build 'gentrification' and London's riverside renaissance. Environment and Planning A 37.7, 1165-90.

Desage, F. and D. Guéranguer (2011) La politique confisquée. Sociologie des réformes et des institutions intercommunales [Confiscating politics. Sociology of intercommunal reforms and institutions]. Éditions du Croquant, Paris.

Epstein, R. and T. Kirszbaum (2003) L'enjeu de la mixité sociale dans les politiques urbaines [The stakes of social mix in urban politics]. Regards sur l'Actualité $292,63-73$. 
Fainstein, S. (2010) The just city. Cornell University Press, Ithaca, NY

Filion, P. (2014) Suburban inertia: the entrenchment of dispersed suburbanism. International Journal of Urban and Regional Research 39.3, 633-40.

Hoffmann-Martinot, V. (2005) Metropolitanization and political change in France in a comparative perspective: the international metropolitan observatory (IMO) project. Paper presented at the Second CNRS-CASS Academic Conference, Institut des Sciences de l'Homme, Lyon, 20-21 June.

Jouve, B. (2001) Lyon recherche gouvernance urbaine désespérément [Lyon desperately seeking urban governance]. Cahiers de géographie du Québec 45.125, 287-92.

Pumain, D. (2005) Urban sprawl: is there a French case? In C.-H.C. Bae and H.W. Richardson (eds.), Urban sprawl in Western Europe and the United States, Ashgate, Aldershot.

Rousseau, M. (2009) Re-imaging the city centre for the middle classes: regeneration, gentrification and symbolic policies in 'loser cities'. International Journal of Urban and Regional Research 33.3, 770-88.
Rousseau, M. (2012) Public mobility as the defining feature of the French post-industrial city. Theory Culture \& Society 29.6, 125-45.

Sénécal, G., A. Germain and J. Benard (2002) Portrait des pratiques communautaires et locales en revitalisation urbaine et sociale sur le territoire de l'île de Montréal [A picture of the community and local initiatives for urban and social regeneration in the territory of the Island of Montreal]. INRS Urbanisation, Culture et Société, Montréal.

Steinmetz, H. (2013) Les chalandonnettes. La production par le haut d'une accession bas de gamme [The 'chalandonnettes'. The top-down production of a bottom-end purchase]. Politix 101, 21-48.

Tissot, S. (2008) 'French suburbs': a new problem or a new approach to social exclusion? Center for European Studies Working Paper Series 160, Harvard University Cambridge, MA

Uitermark, J., J.W. Duyvendak and R. Kleinhans (2007) Gentrification as a governmental strategy: social control and social cohesion in Hoogvliet, Rotterdam. Environment and Planning A 39.1, 125-41.

Wacquant, L. (2006) Parias urbains. Ghetto, banlieues, etat [Urban outcasts. Ghetto, suburbs and the state]. La Découverte, Paris. 